\title{
Effects of Spirogyra jaoensis as a dietary supplement on growth, pectoralis muscle performance, and small intestine morphology of broiler chickens
}

\author{
H. T. Saragih ${ }^{1}$, A. A. K. Muhamad ${ }^{1}$, Alfianto Alfianto ${ }^{1}$, F. Viniwidihastuti ${ }^{1}$, L. F. Untari ${ }^{1}$, I. Lesmana ${ }^{1}$, \\ H. Widyatmoko ${ }^{2}$ and Z. Rohmah ${ }^{1}$
}
1. Department of Animal Development Structure, Faculty of Biology, Universitas Gadjah Mada, Yogyakarta, 55281, Indonesia; 2. Department of Research and Development, Sari Rosa Asih Company, Yogyakarta, Indonesia.
Corresponding author: H. T. Saragih, e-mail: saragihendry@ugm.ac.id
Co-authors: AAKM: akhowarizmi.avisienna.k@mail.ugm.ac.id, AA: alfianto@mail.ugm.ac.id, FV: viniwidi@gmail.com, LFU: ludmilla.untari@ugm.ac.id, IL: indra.lesmana@ugm.ac.id, HW: hestuwidyatmoko@gmail.com, ZR: zuliyati.rohmah@ugm.ac.id
Received: 24-04-2019, Accepted: 28-06-2019, Published online: 11-08-2019

doi: 10.14202/vetworld.2019.1233-1239 How to cite this article: Saragih HT, Muhamad AAK, Alfianto A, Viniwidihastuti F, Untari LF, Lesmana I, Widyatmoko H, Rohmah Z (2019) Effects of Spirogyra jaoensis as a dietary supplement on growth, pectoralis muscle performance, and small intestine morphology of broiler chickens, Veterinary World, 12(8): 1233-1239.

\begin{abstract}
Aim: This study aimed to examine the effect of dietary Spirogyra jaoensis in starter feed on growth performance, pectoralis muscle (PM) growth, and small intestine morphology of broiler chickens.

Materials and Methods: One hundred twenty one-day-old Cobb-500 broilers (body weight $46 \pm 2.6$ g) were divided into four equal groups with 3 replicates in each group and given basal feed supplemented with dried S. jaoensis at doses of $0 \%$, $0.5 \%, 1 \%$, or $2 \%$. The treatment was carried out until the chickens were 18 days old to examine growth of broiler chicks at starter period (8-21 days old).

Results: Supplementation with S. jaoensis at doses of $0.5 \%$ and $1 \%$ resulted in increased weight and improved feed conversion ratio compared to the control group. At the end of treatment, chickens fed with $0.5 \%$ and $1 \%$ S. jaoensis weighed $428.3 \pm 47.8 \mathrm{~g}$ and $426.9 \pm 31.8 \mathrm{~g}$, respectively, and were significantly heavier than the control group $(373.1 \pm 44.1 \mathrm{~g})$. Furthermore, parameters related to PM growth and small intestine morphology of chickens supplemented with $0.5 \%$ $S$. jaoensis in basal feed were improved compared to the control group.
\end{abstract}

Conclusion: The results of this research indicate that $S$. jaoensis at a dose of $0.5 \%$ improves growth performance, PM growth, and small intestine morphology in broiler chickens.

Keywords: broiler chicken, feed supplement, pectoralis muscle growth, small intestine, Spirogyra jaoensis.

\section{Introduction}

In Indonesia, market demand for protein derived from animals is very high. The four main sources of animal-derived protein are pigs, cows, goats, and chickens, the biggest being chicken (Gallus gallus domesticus L.) with a consumption rate of $4.01 \mathrm{~kg} / \mathrm{person} /$ year or $85 \%$ of national fresh meat consumption per capita [1]. To satisfy this high market demand, the poultry industry needs to enhance its production. The yield of production reflects the growth rate and weight gain (WG) of chickens, especially the pectoralis muscle (PM), which represents the majority of consumed muscle $[2,3]$. In an effort to maximize the performance of chickens to meet the demands of consumers, nutritional factors play a pivotal part along with genetic factors [4-8]. A previous study reported that high nutritive feed is important for health

Copyright: Saragih, et al. Open Access. This article is distributed under the terms of the Creative Commons Attribution 4.0 International License (http://creativecommons.org/licenses/ by/4.0/), which permits unrestricted use, distribution, and reproduction in any medium, provided you give appropriate credit to the original author(s) and the source, provide a link to the Creative Commons license, and indicate if changes were made. The Creative Commons Public Domain Dedication waiver (http:// creativecommons.org/publicdomain/zero/1.0/) applies to the data made available in this article, unless otherwise stated. and development of the digestive system of chickens, which, in turn, will promote weight growth, especially if given immediately after hatching [9].

The important characteristics of chicken feed for optimum growth are the availability and ratio of protein, carbohydrates, and fats [10]. The need for protein in chicken feed is satisfied by soybean meal and corn ingredients. At present, soybean meal ingredients used by chicken feed manufacturers in Indonesia are almost completely obtained through importation [11]. Hence, alternative material is needed to forestall any difficulties with the availability of soybean meal in the future.

Spirogyra is a genus of filamentous algae, which normally live floating freely in freshwater. The chemical composition of Spirogyra spp. consists of 12-24\% protein, $43-62 \%$ carbohydrate, and $15-21 \%$ fat [12]. In addition, Spirogyra neglecta is known to have antibacterial, anticancer, antidiabetic, and antioxidant properties in the rat model [13-16]. S. neglecta also has immunomodulatory activity when tested on animal cell cultures [17]. A species of Spirogyra that is commonly found in Java, Indonesia, is Spirogyra jaoensis, although this alga has not been widely studied either for health or as a dietary component for chickens. 
This study aimed, to explore the potential of $S$. jaoensis as a new feed supplement and to determine the effect of dietary $S$. jaoensis on growth performance, PM growth, and small intestine morphology of broiler chickens.

\section{Materials and Methods}

\section{Ethical approval}

Ethical approval was obtained from the Universitas Gadjah Mada Integrated Research and Testing Laboratory (LPPT UGM), with No. 00039/04/ LPPT/IV/2018.

\section{Treatment feed formulation and preparation}

Spirogyra spp. algae were obtained from fields in Sleman Regency, Yogyakarta, Indonesia, and identified as S. jaoensis in the Plant Systematics Laboratory, Faculty of Biology, Gadjah Mada University. Proximate composition of $S$. jaoensis was determined before feed treatment (Table-1). Ash, moisture, and carbohydrate content were determined with methods according to the Association of Official Agricultural Chemists [18]. Crude protein, fat, and fiber contents were analyzed with methods described by Pearson [19]. S. jaoensis was washed and air-dried at room temperature for 1 day and then dried in incubator at $50^{\circ} \mathrm{C}$ for 3 days. The dried $S$. jaoensis was then pulverized to a fine powder, using a domestic blender, which was used to supplement the basal feed. A bomb calorimeter test was also conducted to calculate the metabolizable energy of $S$. jaoensis supplemented feed (Table-1).

\section{Feed treatment}

One hundred twenty 1-day-old chicks (DOCs) with an average weight of $46 \pm 2.6 \mathrm{~g}$ were obtained from Sabar Poultry Shop, Indonesia. Before treatment, the DOCs were allotted randomly into four groups with 3 replicates in each group and a sex ratio of 50:50 within groups. The cages were of a size suitable to house $8-12 \mathrm{DOCs} / \mathrm{m}^{2}$. The cages were kept in a temperature-controlled room. The temperature was maintained at $29-31^{\circ} \mathrm{C}$ and checked twice a day. Cages and room conditions were compiled rearing standards for broiler DOCs. Feed and water were given ad libitum, and fresh feed and water were supplied in the morning and evening. DOCs were acclimatized until 3 days old. To examine the effect of $S$. jaoensis supplementation on growth of broiler chicks at starter period (8-21 days old), the treatment feed was given to DOCs until 18 days old. Group 1 was

Table-1: Nutritional content of Spirogyra jaoensis.

\begin{tabular}{lc}
\hline Parameter & Value \\
\hline Crude protein (\%) & 18 \\
Crude fiber (\%) & 37 \\
Crude fat (\%) & 5.5 \\
Ash (\%) & 28 \\
Moisture (\%) & 11 \\
Metabolizable & 2174 \\
energy (kcal/kg) & \\
\hline
\end{tabular}

designated as the $\mathrm{K} 0$ group and given basal feed without any supplementation. Groups 2 (P1), 3 (P2), and 4 (P3) were given basal feed supplemented with $0.5 \%$, $1 \%$, and $2 \% S$. jaoensis, respectively.

All the chicks were weighed at age 0 (posthatch), 3, $69,12,15$, and 18 days old. The weights of feed provided and left uneaten were recorded daily to calculate the amount of feed consumed (feed intake $[\mathrm{FI}]$ ). The feed conversion ratio (FCR) was calculated as the FI needed to gain $1 \mathrm{~kg}$ in weight (WG) $[20,21]$ :

$$
\mathrm{FCR}=\mathrm{FI} / \mathrm{WG}
$$

\section{Measurement of small intestine morphology}

On the final day of treatment (day 18), all chicks were fasted and eight from each group were euthanized. The small intestine (duodenum, jejunum, and ileum) was excised and prepared for histological examination using the paraffin method [22]. Histological slides were visualized by periodic acid-Schiff staining [23]. Small intestine microscopic morphology was documented using a Leica microscope digital camera system and software. Villus height, crypt depth, and goblet cell area were measured using Image Raster 3.0 software (Miconos Transdata, Indonesia) [24].

\section{PM observation}

The PM was excised, and the left half of the muscle was weighed while the right half was photographed and measured for PM area with ImageJ software (NIHUSA). For histological analysis, $3 \mathrm{~cm} \times 3 \mathrm{~cm}$ of muscle tissue was processed using the paraffin method and hematoxylin-eosin staining. The histological slides of muscle were then observed and measured for fasciculus and myofiber size/area using ImageJ [25].

\section{Statistical analysis}

Data on body weight, FCR, small intestine morphology, and PM parameters were analyzed using one-way analysis of variance (ANOVA), followed by Tukey's test at a confidence threshold of 5\%.

\section{Results}

\section{Growth performance}

The effects of various doses of S. jaoensis on growth performance of broiler chickens are shown in Figure-1 and Table-2. Chickens fed basal feed supplemented with $S$. jaoensis at $0.5 \%$ and $1 \%$ (P1 and P2) had higher WG compared to both the K0 group and the treatment group supplemented with $2 \%(\mathrm{P} 3)$ S. jaoensis. The increased WG with $0.5 \%$ and $1 \%$ $S$. jaoensis supplementation compared to the K0 group began at the age of 6 days old and continued to 18 days old. WG of broilers fed with $S$. jaoensis at doses of $0.5 \%, 1 \%$, and $2 \%$ was $29.7 \pm 18 \mathrm{~g} / \mathrm{day}, 25.5 \pm 11.8 \mathrm{~g} /$ day, and $23.7 \pm 16.6 \mathrm{~g} /$ day, respectively. These rates are greater than that of the K0 group $(19.3 \pm 10.5 \mathrm{~g}$ /day), although none of these differences are significant. The FCR values of all four groups were similar.

\section{PM growth}

The effects of various doses of $S$. jaoensis feed supplementation on PM growth of broiler chickens 
are presented in Table-3 and Figure-2. The weight, area, fasciculus, and myofiber area of PM of the P1 and $\mathrm{P} 2$ treatment groups were higher than those of the $\mathrm{K} 0$ and $\mathrm{P} 3$ treatment groups. The muscle weight of P1 (35.5 $\pm 3.6 \mathrm{~g})$ was significantly higher than those of $\mathrm{K} 0(28.04 \pm 2.8 \mathrm{~g}), \mathrm{P} 2(27.7 \pm 1.7 \mathrm{~g})$, and
P3 $(28.8 \pm 3.6 \mathrm{~g})$. The PM area of treatment groups was $61.6 \pm 8.8 \mathrm{~mm}^{2}, 53.6 \pm 8.4 \mathrm{~mm}^{2}$, and $53.9 \pm 7.8$ $\mathrm{mm}^{2}$ for $\mathrm{P} 1, \mathrm{P} 2$, and $\mathrm{P} 3$, respectively, and $48.4 \pm 4.2$ $\mathrm{mm}^{2}$ for $\mathrm{K} 0$. The PM area values of $\mathrm{P} 1, \mathrm{P} 2$, and P3 were all significantly higher than that of K0 $(\mathrm{p}<0.05)$.

Table-2: Effects of dietary Spirogyra jaoensis on the performance of broiler chickens at 18 days old.

\begin{tabular}{lcccc}
\hline Variable & K0 & P1 & P2 & P3 \\
\hline Feed intake $(\mathrm{g} /$ day) & $28.81 \pm 12.5^{\text {ns }}$ & $35.79 \pm 14.08^{\text {ns }}$ & $35.40 \pm 13.31^{\text {ns }}$ & $30.16 \pm 13.6^{\text {ns }}$ \\
Weight gain (g/day) & $19.28 \pm 10.5^{\text {ns }}$ & $29.56 \pm 17.98^{\text {ns }}$ & $25.52 \pm 11.79^{\text {ns }}$ & $23.69 \pm 16.55^{\text {ns }}$ \\
FCR $\left(\mu \mathrm{m}^{2}\right)$ & $1.76 \pm 0.95^{\text {ns }}$ & $1.45 \pm 0.75^{\text {ns }}$ & $1.51 \pm 0.54^{\text {ns }}$ & $1.44 \pm 0.56^{\text {ns }}$ \\
\hline
\end{tabular}

Numbers in a particular row that is followed by different letters are significantly different from each other $(p<0.05)$. ns $=$ no significant differences within the row. FCR=Feed conversion ratio

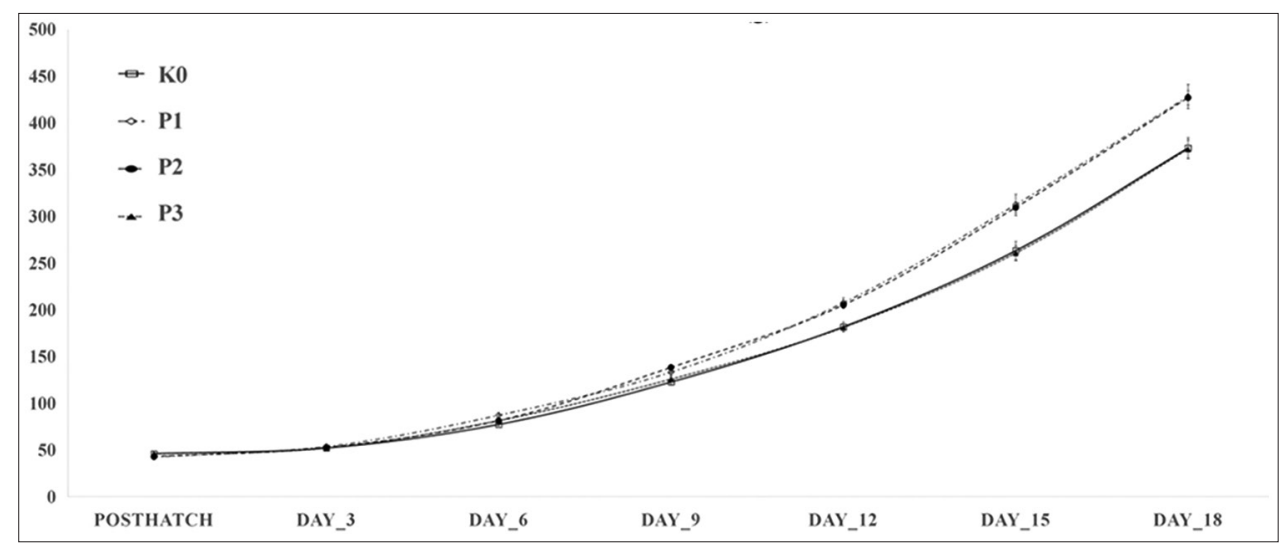

Figure-1: Effects of dietary Spirogyra jaoensis on bodyweight ( \pm standard error median) of broiler chickens from post-hatch until 18 days of age. $\mathrm{K} 0=$ Control group with basal feed, $\mathrm{P} 1=$ Chicks treated with basal feed $+S$. jaoensis $(0.5 \%$ of feed), $\mathrm{P} 2=$ Chicks treated with basal feed $+S$. jaoensis $(1 \%$ of feed), $\mathrm{P} 3=$ Chicks treated with basal feed $+S$. jaoensis ( $2 \%$ of feed).

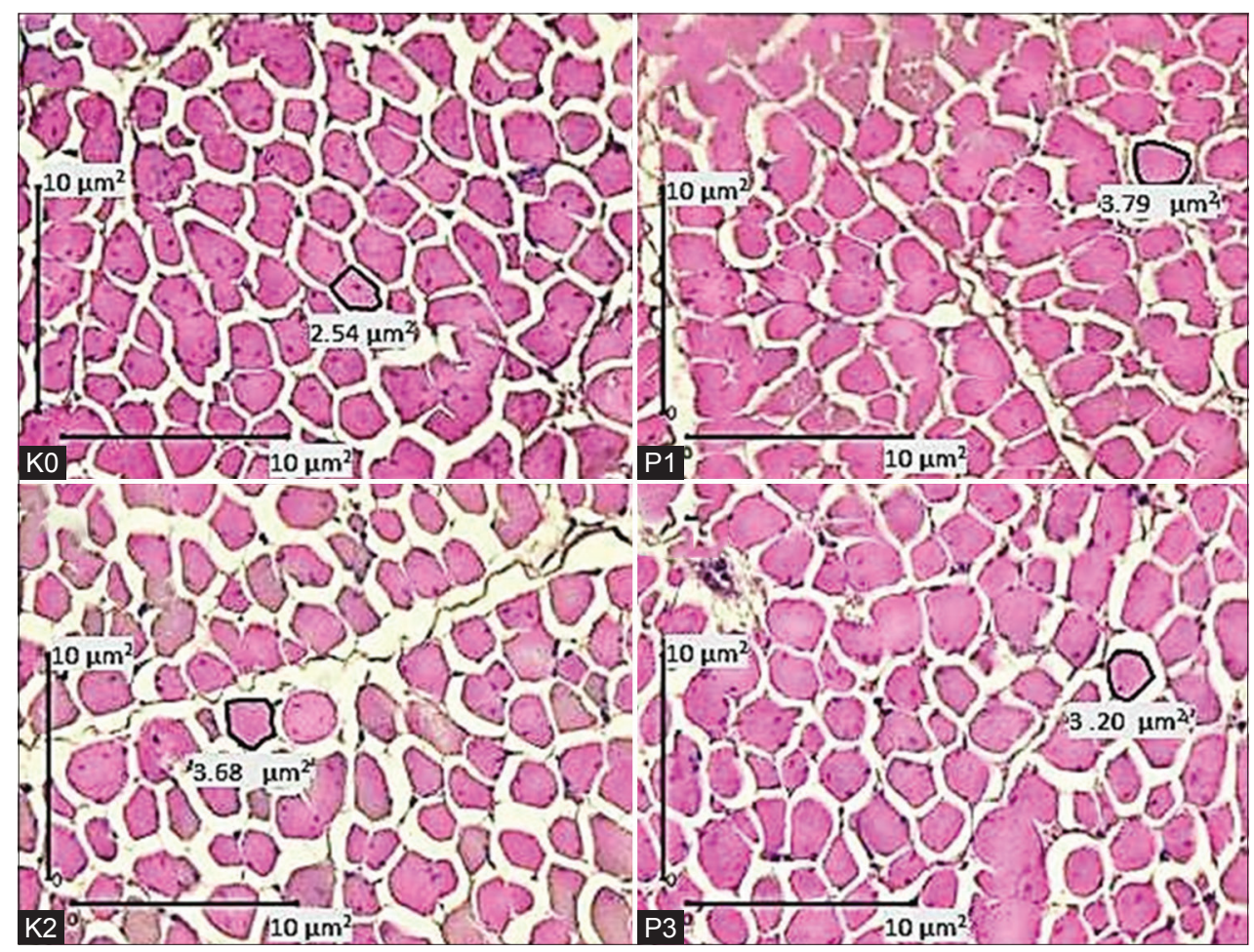

Figure-2: Sections of pectoralis muscle tissue of broiler chickens. $\mathrm{K} 0=$ Control group with basal feed, $\mathrm{P} 1=\mathrm{Chicks}$ treated with basal feed+Spirogyra jaoensis $(0.5 \%$ of feed), P2 $=$ Chicks treated with basal feed + S. jaoensis $(1 \%$ of feed), P3=Chicks treated with basal feed $+S$. jaoensis ( $2 \%$ of feed). In the control, the myofiber area is smaller than that in chicks fed with S. jaoensis. Hematoxylin and eosin staining. 


\section{Small intestine morphology}

The effect of $S$. jaoensis in basal feed on intestinal morphology of broiler chickens is shown in Table-4. The villus of the duodenum in P1 $(733.0 \pm 41.1 \mu \mathrm{m})$ was significantly higher than those of K0 $(663.4 \pm 39.1 \mu \mathrm{m}), \mathrm{P} 2(671.6 \pm 13.9 \mu \mathrm{m})$, and $\mathrm{P} 3(656.0 \pm 29.7 \mu \mathrm{m})$; this was also the case for the villus of the jejunum. Moreover, the villus of ileum in P1 and P2 was significantly higher than those in $\mathrm{K} 0$ and P3. Crypt depth in the duodenum and ileum of treatment groups was higher than that of control, although there was no significant difference in jejunum crypt depth between any groups. In general, the number and size of goblet cells in the small intestine of treatment groups were higher than those of control, especially in P1 and P2.

\section{Discussion}

Algae have many benefits as food sources and animal feed additives [26-29]. In chickens, algae are known to increase immunity, help the digestive system, and have a positive effect on the quality of meat products and chicken eggs [30-32].
The previous studies reported that the protein content in chicken feed had a considerable influence on the growth of chickens and also increased the efficiency of the digestive system $[33,34]$. In our study, supplementation with $S$. jaoensis in broiler chickens could enhance weight increase and improve FCR compared to the control group. These results were consistent with previous research reporting that the administration of $S$. ellipsospora could also stimulate WG in broiler chickens [35]. S. jaoensis used in this research has a content of $16 \%$ protein, $36 \%$ carbohydrate, and $11 \%$ lipid (Table-1), which we believe influenced the growth of broiler chickens.

PM growth is an important indicator of the success of broiler chicken growth [36]. The PM is often used as a parameter for chicken muscle growth due to its lack of fat accumulation [37]. A good level of protein in chicken feed is very important for PM growth: Proteins are known to stimulate the proliferation of satellite cells to regenerate myofiber cells for better muscle growth [38]. In this research, we observed that muscle growth of pectoralis broiler chickens supplemented with $S$. jaoensis in feed was improved (Table-3

Table-3: Effects of dietary Spirogyra jaoensis on the pectoralis muscle of broiler chickens at 18 days old.

\begin{tabular}{|c|c|c|c|c|c|}
\hline Variable & KO & P1 & $\mathbf{P 2}$ & P3 & p-value \\
\hline Muscle weight (g) & $28.04 \pm 2.82^{a}$ & $35.51 \pm 3.61^{b}$ & $27.73 \pm 1.71^{\mathrm{a}}$ & $28.76 \pm 3.59^{a}$ & 0.001 \\
\hline Muscle area $\left(\mathrm{mm}^{2}\right)$ & $48.37 \pm 4.24^{a}$ & $61.62 \pm 8.76^{b}$ & $53.58 \pm 8.44^{\mathrm{ab}}$ & $53.88 \pm 7.80^{\mathrm{ab}}$ & 0.039 \\
\hline Fasciculus area $\left(\mu \mathrm{m}^{2}\right)$ & $536.75 \pm 45.88^{a}$ & $683.25 \pm 19.31^{b}$ & $579.91 \pm 28.64^{a}$ & $563.96 \pm 26.54^{a}$ & 0.000 \\
\hline Myofiber area $\left(\mu \mathrm{m}^{2}\right)$ & $3.47 \pm 0.27^{a}$ & $4.38 \pm 0.14^{b}$ & $3.38 \pm 0.34^{a}$ & $3.49 \pm 0.19^{a}$ & 0.000 \\
\hline
\end{tabular}

Numbers in a particular row that is followed by different letters are significantly different from each other $(p<0.05)$

Table-4: Effects of dietary Spirogyra jaoensis on villus height, crypt depth, villus/crypt ratio, number of goblet cells, and area of goblet cells of broiler chickens at 18 days old.

\begin{tabular}{|c|c|c|c|c|c|}
\hline Variable & KO & P1 & $\mathbf{P 2}$ & P3 & P-value \\
\hline \multicolumn{6}{|l|}{ Duodenum } \\
\hline Villus height $(\mu \mathrm{m})$ & $663.4 \pm 39.09^{a}$ & $733 \pm 41.13^{b}$ & $671.6 \pm 13.87^{a}$ & $656 \pm 29.64^{a}$ & 0.019 \\
\hline Crypt depth $(\mu \mathrm{m})$ & $104.2 \pm 11.03^{a}$ & $136.8 \pm 29.75^{b}$ & $118.2 \pm 13.99^{a b}$ & $106 \pm 7.78^{\mathrm{ab}}$ & 0.046 \\
\hline Ratio V/C & $6.37 \pm 0.49^{a}$ & $5.48 \pm 0.80^{\mathrm{a}}$ & $5.74 \pm 0.72^{a}$ & $6.16 \pm 0.27^{a}$ & 0.132 \\
\hline $\begin{array}{l}\text { Number of goblet } \\
\text { cells/100 cells }\end{array}$ & $53.6 \pm 3.05^{\mathrm{a}}$ & $67.6 \pm 1.82^{c}$ & $59.2 \pm 1.92^{\mathrm{ab}}$ & $55.8 \pm 2.28^{\mathrm{ab}}$ & 0.000 \\
\hline $\begin{array}{l}\text { Area of goblet } \\
\text { cells }\left(\mu \mathrm{m}^{2}\right)\end{array}$ & $7.08 \pm 0.26^{a}$ & $7.88 \pm 0.31^{b}$ & $7.09 \pm 0.22^{\mathrm{a}}$ & $7.04 \pm 0.15^{a}$ & 0.001 \\
\hline \multicolumn{6}{|l|}{ Jejunum } \\
\hline Villus height $(\mu \mathrm{m})$ & $466.59 \pm 10.53^{a}$ & $550.76 \pm 37.16^{b}$ & $488.15 \pm 5.71^{\mathrm{a}}$ & $473.95 \pm 3.52^{\mathrm{a}}$ & 0.000 \\
\hline Crypt depth ( $\mu \mathrm{m})$ & $105.33 \pm 3.97^{a}$ & $105.54 \pm 7.22^{\mathrm{a}}$ & $98.26 \pm 2.26^{\mathrm{a}}$ & $98.87 \pm 2.20^{\mathrm{a}}$ & 0.092 \\
\hline Ratio V/C & $4.43 \pm 0.14^{a}$ & $5.22 \pm 0.20^{c}$ & $4.97 \pm 0.17^{\mathrm{bc}}$ & $4.79 \pm 0.07^{b}$ & 0.000 \\
\hline $\begin{array}{l}\text { Number of goblet } \\
\text { cells/100 cells }\end{array}$ & $26.6 \pm 1.14^{\mathrm{ab}}$ & $30.2 \pm 1.48^{c}$ & $27.2 \pm 0.84^{\mathrm{ab}}$ & $24.8 \pm 0.84^{a}$ & 0.001 \\
\hline $\begin{array}{l}\text { Area of goblet } \\
\text { cells }\left(\mu \mathrm{m}^{2}\right)\end{array}$ & $6.38 \pm 0.10^{a}$ & $7.78 \pm 0.11^{c}$ & $7.07 \pm 0.16^{b}$ & $6.54 \pm 0.04^{a}$ & 0.000 \\
\hline \multicolumn{6}{|l|}{ Ileum } \\
\hline Villus height $(\mu \mathrm{m})$ & $384.19 \pm 6.77^{a}$ & $420.96 \pm 10.05^{c}$ & $399.13 \pm 7.13^{b}$ & $377.23 \pm 5.55^{\mathrm{a}}$ & 0.000 \\
\hline Crypt depth $(\mu \mathrm{m})$ & $82.15 \pm 2.58^{\mathrm{ab}}$ & $84.93 \pm 3.37^{\mathrm{bc}}$ & $86.93 \pm 1.65^{c}$ & $79.47 \pm 1.52^{\mathrm{a}}$ & 0.029 \\
\hline Ratio V/C & $4.68 \pm 0.09^{a}$ & $4.96 \pm 0.11^{\mathrm{b}}$ & $4.59 \pm 0.06^{\mathrm{a}}$ & $4.75 \pm 0.09^{a}$ & 0.001 \\
\hline $\begin{array}{l}\text { Number of goblet } \\
\text { cells } / 100 \text { cells }\end{array}$ & $30.20 \pm 2.28^{a}$ & $38.8 \pm 1.09^{c}$ & $35.40 \pm 1.14^{b}$ & $30.8 \pm 1.64^{a}$ & 0.000 \\
\hline $\begin{array}{l}\text { Area of goblet } \\
\text { cells }\left(\mu \mathrm{m}^{2}\right)\end{array}$ & $6.89 \pm 0.12^{\mathrm{a}}$ & $8.91 \pm 0.25^{c}$ & $7.59 \pm 0.09^{b}$ & $6.99 \pm 0.11^{a}$ & 0.000 \\
\hline
\end{tabular}

Numbers in a particular row that is followed by different letters are significantly different from each other $(p<0.05)$. $\mathrm{V} / \mathrm{C}=$ Villus height/crypt depth 
and Figure-3). Even though there were no significant differences for FCR, daily growth, or FI, there was a tendency for body and PM weight to increase in treatment groups. This can be attributed to the high protein, lipid, and carbohydrate content of $S$. jaoensis. These components increased the calorie count in basal feed (Table-5), which, thus, became an improved source of energy for growth.

The small intestine is an important site for the absorption process in chickens. It consists of the duodenum, jejunum, and ileum, all of which have absorption functions. Efficiency in the absorption of food nutrients is influenced by tissue structure in the small intestine, especially in villus length, crypt depth, and optimal goblet cell numbers for secreting mucin. Villi in the small intestine play a role in the absorption of nutrients by increasing the surface area of the intestine [39]. The role of the crypt is to accelerate the repair of villus tissue that has been damaged by exfoliation, inflammation, or toxins originating from pathogens. Villus height is directly proportional to crypt depth and can be used as an indicator of good small intestinal morphology: A low villus height/crypt depth ratio indicates good absorption of nutrients [21]. In this research, the morphology of the small intestine in treatment groups (Table-4 and Figure-1) showed an improvement over the control group. This suggested that fiber present in S. jaoensis had a positive impact on intestinal morphology, which, in turn, made the small intestine more effective in nutrient absorption. This result is in agreement with a previous report that the presence of high free fiber from Trichoderma fermented wheat bran in diet could improve small intestine morphology in broiler chickens [40].

Goblet cells also have an important role in synthesizing mucin, a glycoprotein that helps to maintain the ecology of the intestine by excluding germs and preventing epithelial degradation [41]. The wider the area of goblet cells and the greater the number of goblet cells, the more effective is the protection of the surface area of villi from pathogen attack. The results of our research showed that administration of $S$. jaoensis increased the number and area of goblet cells (Table-4), suggesting that mucin production in the small intestine is higher in the treatment groups. Elevated intestinal mucin along with higher epithelial turnover may increase the effectiveness of the small intestine in nutrient absorption [42].

\section{Conclusion}

This research indicates that supplementing feed with the alga $S$. jaoensis at a dose of $0.5 \%$ has the

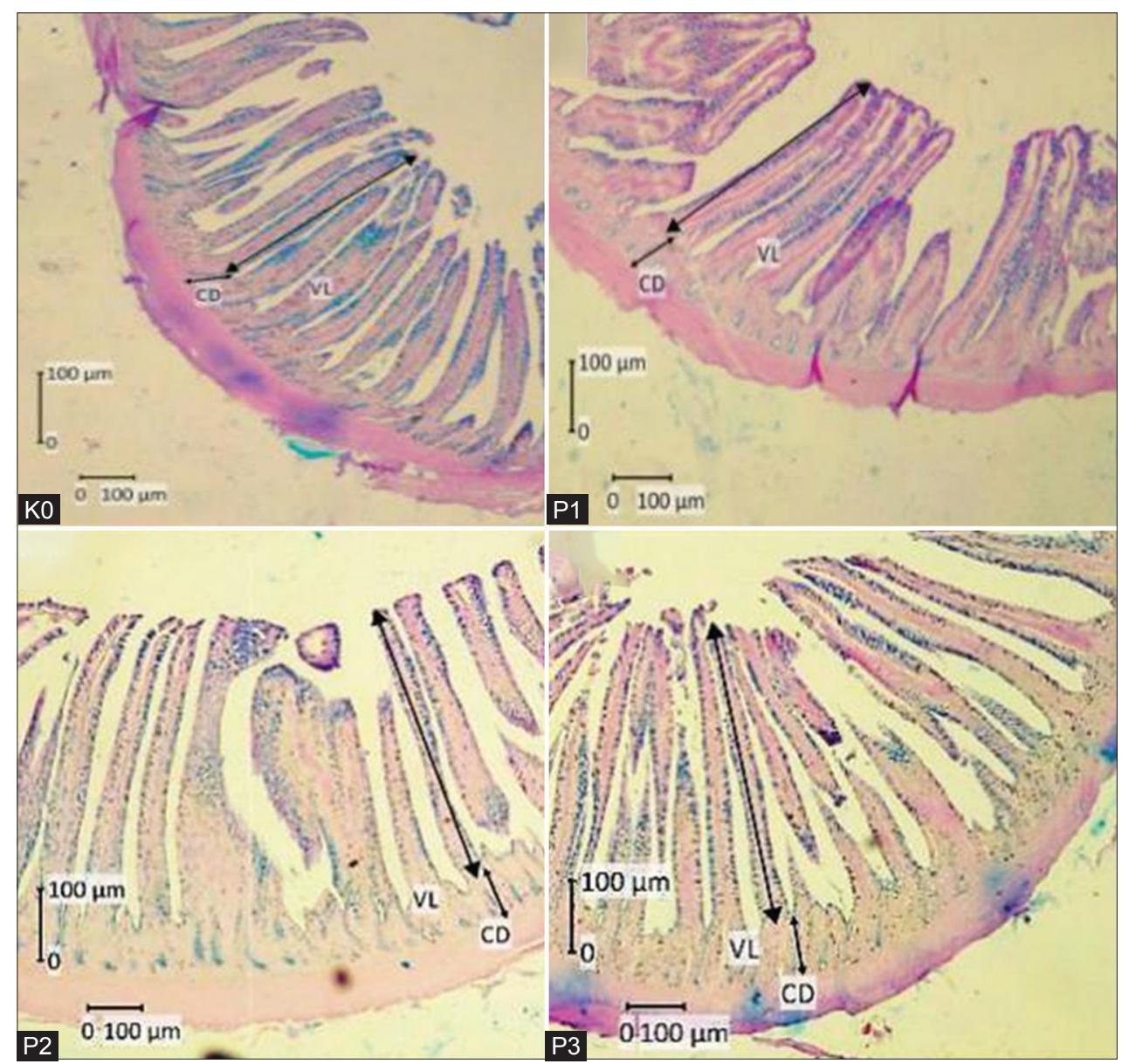

Figure-3: Sections of jejunum tissue of broiler chickens. $\mathrm{K} 0=$ Control group with basal feed, $\mathrm{P} 1=$ Chicks treated with basal feed+Spirogyra jaoensis $(0.5 \%$ of feed $), P 2=$ Chicks treated with basal feed $+S$. jaoensis $(1 \%$ of feed $), P 3=C h i c k s$ treated with basal feed $+S$. jaoensis ( $2 \%$ of feed). In the control, the villi are shorter and thicker than those in chicks fed with S. jaoensis, $C D=$ Crypt depth, VL=Villus length, Periodic acid-Schiff staining. 
Table-5: Basal feed formulation, treatment feed proximate composition, and calorimetric analysis for feed treatment with Spirogyra jaoensis supplementation.

\begin{tabular}{|c|c|c|c|c|}
\hline \multirow[t]{3}{*}{ Composition of feed $(\%)$} & \multicolumn{4}{|c|}{ Starter } \\
\hline & \multicolumn{4}{|c|}{ Spirogyra jaoensis (\%) } \\
\hline & $\mathbf{0}$ & 0.5 & 1 & 2 \\
\hline Corn & 49.0 & 49.0 & 49.0 & 49.0 \\
\hline Soybean meal & 29.0 & 29 & 29 & 29 \\
\hline Rice bran & 9.8 & 9.8 & 9.8 & 9.8 \\
\hline Full-fat soya & 5.4 & 5.4 & 5.4 & 5.4 \\
\hline Crude palm oil & 3.0 & 3.0 & 3.0 & 3.0 \\
\hline Dicalcium phosphate & 2.37 & 2.37 & 2.37 & 2.37 \\
\hline Premix vitamin & 0.03 & 0.03 & 0.03 & 0.03 \\
\hline Premix mineral & 0.06 & 0.06 & 0.06 & 0.06 \\
\hline D,L-methionine & 0.22 & 0.22 & 0.22 & 0.22 \\
\hline $\mathrm{NaCl}$ & 0.32 & 0.32 & 0.32 & 0.32 \\
\hline Calcite & 0.5 & 0.5 & 0.5 & 0.5 \\
\hline L-lysine $\mathrm{HCl}$ & 0.1 & 0.1 & 0.1 & 0.1 \\
\hline L-threonine & 0.04 & 0.04 & 0.04 & 0.04 \\
\hline Choline chloride $60 \%$ & 0.16 & 0.16 & 0.16 & 0.16 \\
\hline \multicolumn{5}{|l|}{ Calculated composition } \\
\hline $\begin{array}{l}\text { Metabolizable energy of } \\
\text { poultry }(\mathrm{kcal} / \mathrm{kg})\end{array}$ & 2904.02 & 2914.89 & 2925.76 & 2947.5 \\
\hline Crude protein (\%) & 20.23 & 20.23 & 20.23 & 20.23 \\
\hline Crude fat $(\%)$ & 8.30 & 8.30 & 8.30 & 8.30 \\
\hline Fiber $(\%)$ & 3.37 & 3.37 & 3.37 & 3.37 \\
\hline Lysine (\%) & 1.22 & 1.22 & 1.22 & 1.22 \\
\hline Methionine (\%) & 0.53 & 0.53 & 0.53 & 0.53 \\
\hline Methionine+cysteine (\%) & 0.86 & 0.86 & 0.86 & 0.86 \\
\hline Calcium (\%) & 1 & 1 & 1 & 1 \\
\hline Phosphorus, total (\%) & 0.95 & 0.95 & 0.95 & 0.95 \\
\hline Phosphorus, available (\%) & 0.5 & 0.5 & 0.5 & 0.5 \\
\hline Sodium (\%) & 0.15 & 0.15 & 0.15 & 0.15 \\
\hline Chloride (\%) & 0.23 & 0.23 & 0.23 & 0.23 \\
\hline
\end{tabular}

potential to improve growth performance, PM growth, and small intestine morphology in broiler chickens.

\section{Authors' Contributions}

HTS, AAKM, AA, and FV contributed equally to the experimentation. HTS, IL, and ZR wrote and edited the article. HTS, LFU, and HW equally designed the experiment. All authors read and approved the final manuscript.

\section{Acknowledgments}

This project was funded by Ministry of Research, Technology and Higher Education, Indonesia with project number 21/UNI/DIKLIT/DIT-LIT/LT/2018.

\section{Competing Interests} interests.

The authors declare that they have no competing

\section{Publisher's Note}

Veterinary World remains neutral with regard to jurisdictional claims in published institutional affiliation.

\section{References}

1. Ditjennak. (2013) Statistik Peternakan dan Kesehatan Hewan. Direktorat Jendral Peternakan dan Kesehatan Hewan, Kementrian Pertanian, Jakarta. (Indonesian Version)

2. Araújo, W.A.G., Albino, L.F.T., Sakomura, N.K.,
Paulino, P.V.R. and Campo, A.M. (2011) Meat quality in "indoor" and "outdoor" production systems of poultry. Open J. Anim. Sci., 1(1): 75-88.

3. Mikulski, D., Celej, J., Jankowski, J., Majewska, T. and Mikulska, M. (2011) Grow performance, carcass traits and meat quality of slower-growing and fast-growing chickens raised with and without outdoor access. Asian Aust. J. Anim. Sci., 24(10): 1407-1416.

4. Petracci, M. and Cavani, C. (2012) Muscle growth and poultry meat quality issues. Nutrients, 4(1): 1-12.

5. Zhao, X.L., Siegel, P.B., Liu, Y.P., Wang, Y., Gilbert, E.R., Zhu, Q. and Zhang, L. (2012) Housing system affects broiler characteristics of local Chinese breed reciprocal crosses. Poult. Sci., 91(9): 2405-2410.

6. Chen, X., Jiang, W., Tan, H.Z., Xu, G.F., Zhang, X.B., Wei, S. and Wang, X.Q. (2013) Effects of outdoor access on growth performance, carcass composition, and meat characteristics of broiler chickens. Poult. Sci., 92(2): 435-443.

7. Moujahed, A. and Haddad, B. (2013) Performance, livability, carcass yield and meat quality of Tunisian local poultry and fast-growing genotype (Arbor Acres) fed standard diet and raised outdoor access. J. Anim. Prod. Adv., 3(3): 75-85.

8. Tong, H.B., Cai, J., Lu, J., Wang, Q., Shao, D. and Zou, J.M. (2015) Effects of outdoor access days on growth performance, carcass yield, meat quality, and lymphoid organ index of a local chicken breed. Poult. Sci., 94(6): 1115-1121.

9. Prabakar, G., Pavulraj, S., Shanmuganathan, S., Kirubakaran, A. and Mohana, N. (2016) Early nutrition and its importance in poultry: A review. Indian J. Anim. Nutr., 33(3): 245-252.

10. Vieira, S.L., Stefanello, C. and Sorbara, J.O.B. (2014) Formulating poultry diets based on their indigestible components. Poult. Sci., 93(9): 2411-2416.

11. Aritonang, P.A., Daryanto, A. and Hendrawan, D.S. (2015) 
Analyzing the relationship between the factors of the marketing and purchasing decisions of soybean meal on livestock feed industry in Indonesia. J. Manage. Appl., 13(3): 474-482. (Indonesian version)

12. Tipnee, S., Ramaraj, R. and Unparom, Y. (2015) Nutritional evaluation of edible freshwater green macroalga Spirogyra varians. Emer. Life Sci. Res., 1(2): 1-7.

13. Thumvijit, T., Inboot, W., Peerapornpisal, Y., Amornlerdpison, D. and Wongpoomchai, R. (2013a) The antimutagenic and antioxidant properties of Spirogyra neglecta (Hassall) Kützing. J. Med. Plants Res., 7(34): 2494-2500.

14. Thumvijit, T., Taya, S., Punvittayagul, C., Peerapornpisal, Y. and Wongpoomchai, R. (2014) Cancer chemopreventive effect of Spirogyra neglecta (Hassall) Kützing on diethylnitrosamine-induced hepatocarcinogenesis in rats. Asian Pac. J. Cancer Prev., 15(4): 1611-1616.

15. Ontawong, A., Saowakon, N., Vivithanaporn, P., Pongchaidecha, A., Lailerd, N., Amornlerdpison, D., Lungkaphin, A. and Srimaroeng, C. (2013) Antioxidant and renoprotective effects of Spirogyra neglecta (Hassall) Kützing extract in experimental Type 2 diabetic rats. Biomed. Res. Int., 2013(3): 1-15.

16. Thumvijit, T., Thuschana, W., Amornlerdpison, D., Peerapornpisal, Y. and Wongpoomchai, R. (2013b) Evaluation of hepatic antioxidant capacities of Spirogyra neglecta (Hassall) Kützing in rats. Interdiscip. Toxicol., 6(3): 152-156.

17. Surayot, U., Wang, J., Lee, J.H., Kanongnuch, C., Peerapornpisal, Y. and You, S.G. (2015) Characterization and immunomodulatory activities of polysaccharides from Spirogyra neglecta (Hassall) Kützing. Biosci. Biotech. Biochem., 79(10): 1644-1653.

18. AOAC. (2005) Official Methods of Analysis. $18^{\text {th }}$ ed. Association of Official Analytical. Chemists International, Maryland, USA.

19. Pearson, D. (1976) The Chemical Analysis of Foods. $7^{\text {th }}$ ed. Churchill Livingstone, London. p3-4.

20. Mountzouris, K.C., Tsirtsikos, P., Kalamara, E., Nitsch, S., Schatzmayr, G. and Fegeros, K. (2007) Evaluation of the efficacy of a probiotic containing Lactobacillus, Bifidobacterium, Enterococcus and Pediococcus strains in promoting broiler performance and modulating cecal microflora composition and metabolic activities. Poult. Sci., 86(2): 309-317.

21. Varkoohi, S., Babak, M.M.S., Pakdel, A., Javaremi, A.N., Zaghari, M. and Kause, A. (2010) Response to selection for feed conversion ratio in Japanese quail. Poult. Sci., 89(8): 1590-1598.

22. Suntoro, S.H. (1983) Metode Pewarnaan (Histologi dan Histokimia). Penerbit Bhratara Karya Aksara, Jakarta, Indonesia.

23. Setiawan, H., Jingga, M.E. and Saragih, H.T. (2018) The effect of cashew leaf extract on small intestine morphology and growth performance of Jawa super chicken. Vet. World, 11(8): 1047-1054.

24. Samanya, M. and Yamauchi, K. (2001) Morphological changes of the intestinal villi in chickens fed the dietary charcoal powder including wood vinegar compounds. J. Poult. Sci., 38(4): 289-301.

25. Velleman, S.G., Coy, C.S., Anderson, J.W., Patterson, R.A. and Nestor, K.E. (2003) Effect of selection for growth rate and inheritance on posthatch muscle development in turkeys. Poult. Sci., 82(9): 1365-1372.

26. Wells, M.L., Potin, P., Craigie, J.S., Raven, J.A., Merchant, S.S., Helliwell, K.E., Smith, A.G., Camire, M.E. and Brawley, S.H. (2017) Algae as nutritional and functional food sources: Revisiting our understanding. $J$. Appl. Phycol., 29(2): 949-982.

27. Fournier, E., Adam, C., Massabuau, J.C. and GarnierLaplace, J. (2005) Selenium bioaccumulation in Chlamydomonas reinhardtii and subsequent transfer to Corbicula fluminea: Role of selenium speciation and bivalve ventilation. Environ. Toxicol. Chem., 25(10): 2692-2699.

28. Gantar, M. and Svircev, Z. (2008) Microalgae and cyanobacteria: food for thought. J. Phycol., 44(2): 260-268.

29. Chacón-Lee, T.L. and González-Mariño, G.E. (2010) Microalgae for "healthy" foods possibilities and challenges. Comp. Rev. Food Sci. Food Saf., 9(6): 655-675.

30. Qadri, S.S.N., Biswas, A., Mandal, A.B., Kumawat, M., Saxena, R. and Nasir, A.M. (2019) Production performance, immune response and carcass traits of broiler chickens fed diet incorporated with Kappaphycus alvarezii. J. Appl. Phycol., 31(1): 753-760.

31. Mobarez-Samia, M., Rizk, A.M., Latif, A.M.A. and El-Sayed, O.A. (2018) Effect of supplementing diet with spirulina platensis algae or turmeric on productive and reproductive performance of golden montazah layers. Egypt. Poult. Sci., 38(1): 109-125.

32. Kovač, D.J., Simeunović, J.B., Babić, O.B., Mišan, A.C. and Milovanović, I.L.J. (2013) Algae in food and feed. Food Feed Res., 40(1): 21-31.

33. Beski, S.S.M., Swick, R.A. and Iji, P.A. (2015) Specialized protein products in broiler chicken nutrition: A review. Anim. Nutr., 1(2): 47-53.

34. Ravindran, V. (2013) Poultry feed availability and nutrition in developing countries. In Poult. Dev. Rev. Rome, Italy: FAO, p. 67-69. 4.

35. Ali, A., Memon, M.S., Sahato, G.A. and Arbani, S.N. (2005) Use of fresh water alga Spirogyra ellipsospora transeau as feed supplement to broiler chicks. Hamdard Med., 48(1): 128-134.

36. Uni, Z. and Ferket, P. (2004) Methods for early nutrition and their potential. World Poult. Sci. J., 60(1): 101-111.

37. Berri, C., Le Bihan-Duval, E., Debut, M., Sante-Lhoutellier, V., Baeza, E., Gigaud, V., Jego, Y. and Duclos, M.J. (2007) Consequence of muscle hypertrophy on characteristics of pectoralis major muscle and breast meat quality of broiler chickens. J. Anim. Sci., 85(8): 2005-2011.

38. Paunesku, T., Mittal, S., Protic, M., Oryhon, J., Korolev, S.V., Joachimiak, A. and Woloschak, G.E. (2001) Proliferating cell nuclear antigen (PCNA): Ringmaster of the genome. Int. J. Radiat. Biol., 77(10): 1007-1021.

39. Adil, S., Banday, T., Bhat, G.A., Mir, M.S. and Rehman, M. (2010) Effect of dietary supplementation of organic acids on performance, intestinal histomorphology, and serum biochemistry of broiler chicken. Vet. Med. Int., 4(3): 1-7.

40. Chu, Y.T., Lo, C.T., Chang, S.C. and Lee, T.T. (2017) Effects of Trichoderma fermented wheat bran on growth performance, intestinal morphology and histological findings in broiler chickens. Ital. J. Anim. Sci., 16(1): 82-92.

41. Brufau, M.T., Martín-Venegas, R., Guerrero-Zamora, A.M., Pérez-Vendrell, A.M., Vilà, B., Brufau, J. and Ferrer, R. (2015) Dietary $\beta$-galactomannans have beneficial effects on the intestinal morphology of chickens challenged with Salmonella enterica serovar Enteritidis. J. Anim. Sci., 93(1): 238-246.

42. Murai, A., Kitahara, K., Terada, H., Ueno, A., Ohmori, Y., Kobayashi, M. and Horio, F. (2018) Ingestion of paddy rice increases intestinal mucin secretion and goblet cell number and prevents dextran sodium sulfate-induced intestinal barrier defect in chickens. Poult. Sci., 97(10): 3577-3586. 